FITRAH Jurnal Kajian Ilmu-ilmu Keislaman

Vol. 03 No. 1 Juni 2017

e-ISSN : 2460-2345, p-ISSN: 2442-6997

Web: jurnal.iain-padangsidimpuan.ac.id/index.php/F

\title{
PROFESI DAN MICROTEACHING BERBASIS NILAI-NILAI ISLAMI
}

\author{
Drs. Zainal Asril, M.Pd.
}

Fakultas Tarbiyah dan Ilmu Keguruan IAIN Imam Bonjol Padang

\begin{abstract}
Teacher is a profesi. In order to produce the professional teachers, some schools or universities have a micro teaching programs. It must be integrated with Islamic values. Teachers must be prepared become a professional teacher, they must have a range of skills, such as the skill to open the lesson, the skill to manage the class, and others. Besides, teacher must also have competencies; they are pedagogical competence, personalitty competence, professional competence, and social competence. Learning and Islam must be integrated to make good educators and students; in order to help them become better and better.
\end{abstract}

Keywords: profesion, integration, skill, competence, and islamic values.

\begin{abstract}
Abstrak
Guru merupakan suatu profesi. Dalam rangka menghasilkan guru yang profesional, ada program micro teaching dalam pembelajaran di kampus-kampus. Pelaksanaannya sebaiknya dilakukan dengan melakukan integrasi dengan nilai - nilai Islam. Guru sebagai tenaga yang harus dipersiapkan untuk menjadi seorang profesional harusnya memiliki berbagai keterampilan, seperti keterampilan membuka pelajaran, keterampilan mengelola kelas, dan lain sebagainya. Selain itu, seorang guru juga harus memiliki beragam kompetensi, seperti kompetensi pedagogik, kompetensi kepribadian, kompetensi profesional, dan kompetensi sosial. Integrasi pembelajaran dengan nilai-nilai Islami sangat diperlukan dalam rangka menghasilkan guru dan peserta didik yang lebih baik.
\end{abstract}

Kata Kunci: profesi, integrasi, keterampilan, kompetensi, dan nilai-nilai Islam.

\section{PENDAHULUAN}

Metamorfosis untuk melahirkan UU tentang Guru dan Dosen telah menempuh perjalanan panjang. Pencanangan Guru sebagai Profesi oleh Presiden Soesilo Bambang Yudhoyono pada tanggal 2 Desember 2004 menjadi salah satu 
FITR AH Jurnal Kajian Ilmu-ilmu Keislaman

Vol. 03 No. 1 Juli 2017

akselerator lahirnya UU No. 14 Tahun 2005. Undang-undang Guru dan Dosen No 14 Tahun 2005 BAB I Pasal 1 menyatakan bahwa Guru adalah pendidik profesional dengan tugas utama adalah mendidik, mengajar, membimbing, mengarahkan, melatih, menilai dan mengevaluasi peserta didik pada pendidikan anak usia dini jalur pendidikan formal, pendidikan dasar, dan pendidikan menengah ${ }^{1}$. Dosen adalah pendidik Profesional dan ilmuan dengan tugas utama adalah mentrasformasikan, mengembangkan, dan menyebar luaskan ilmu pengetahuan, teknologi, seni melalui pendidikan, penelitian dan pengabdian kepada masyarakat. Pascalahirnya UU No. 14 Tahun 2005 tentang Guru dan Dosen, diikuti dengan beberapa produk hukum yang menjadi dasar implementasi kebijakan.

Merujuk pada rumusan Undang-undang guru dan dosen tersebut sangat terlihat bahwa Guru dan dosen sebagai pendidik profesional dihadapkan berbagai tantangan yang sangat holistik dan komprehensif. Peran pendidikan telah bergeser oleh berbagai piranti teknologi sehingga sebahagian peserta didik didewasakan oleh media teknologi terutama teknologi lewat internet dan jejaring sosial. Teknologi memberi pengaruh terhadap keprofesian seseorang pendidik dalam pembelajaran. Terutama dalam Praktek Pengalaman Lapangan (PPL) sehinga calon mahasiswa tidak siap mengajar di sekolah/ madrasah.

\section{PEMBAHASAN}

\section{Profesi Guru}

Konsep dasar profesi dalam pendidikan pada dasarnya sama seperti yang berlaku dalam profesi-profesi lain. Perbedaan terletak pada asumsi-asumsi yang melandasinya tentang manusia dan cara memperlakukan manusia sebagai subjek profesi, karena pada dasarnya manusia dapat di didik dan dilatih. Profesi pendidikan lebih melihat manusia dari segi positifnya dan segi-segi positif inilah yang dikembangkan.

Profesional adalah melakukan sesuatu pekerjaan pokok sebagai profesi bukan sebagai pengisi waktu luang atau sebagai hoby belaka. Seorang profesional mempunyai kebermaknaan ahli (expert) dengan pengetahuan yang dimilki dalam melayani pekerjaannya. Tangung jawab (responsibility) atas keputusannya baik intelektual maupun sikap, dan memiliki rasa kesejawatan

\footnotetext{
${ }^{1}$ Undang-undang Guru dan Dosen No 14 Tahun 2005.
} 
menjunjung tinggi etika profesi dalam suatu organisasi yang dinamis. Seorang profesional memberikan layanan pekerjaan secara terstruktur. Jadi seorang bekerja profasional akan menampakan adanya keterampilan teknis yang didukung oleh sikap kepribadian tertentu yang dilandasi oleh pedomanpedoman tingkah laku yang khusus (kode etik). Pasal 1 ayat 4 Undang-undang Guru dan Dosen mengemukakan bahwa, Profesional adalah pekerjaan atau kegiatan yang dilakukan seseorang dan menjadi sumber penghasilan kehidupan yang memerlukan keahlian, kemahiran, atau kecakapan yang memenuhi standar mutu atau norma tertentu serta memerlukan pendidikan Profesi.

Seorang profesional memiliki kompetensi, kompetensi itu sendiri adalah kemampuan untuk mengerjakan sesuatu pekerjaan. Orang yang memiliki kompetensi dia akan mampu (1) melakukan sesuatu pekerjaan tertentu secara rasional. (2) Menguasai perangkat ilmu pengetahuan (teori, konsep), (3) Menguasai perangkat keterampilan (metode, model, keterampilan, strategi) (4) Memahami perangkat persyaratan normatif. (5) Unggul dalam melaksanakan tugas pekerjaanya. (6) Memiliki kewenangan dalam penguasaan kompetensi dalam skala batas-batas tertentu.

Apakah yang dimaksud dengan kompetensi itu ? Badan Standar Nasional Pendidikan (BSNP) mengembangkan standar kompetensi guru dan dosen, karena badan inilah yang memiliki kewenangan untuk mengembangkan standar kompetensi guru dan dosen yang hasilnya ditetapkan dengan Peraturan Menteri. Namun demikian dapat dicermati pendapat Johnson yang mengatakan kompetensi merupakan perilaku rasional guna mencapai tujuan yang dipersyaratkan sesuai dengan kondisi yang diharapkan². Menurut UU No. 14 tahun 2005 tentang Guru dan Dosen pasal 1, ayat 10, disebutkan "kompetensi adalah perangakat pengetahuan, keterampilan, dan perilaku yang harus dimiliki, dihayati, dan dikuasai oleh guru atau dosen dalam melaksanakan tugas keprofesional"3. Kompetensi merupakan peleburan dari pengetahuan (daya pikir), sikap (daya kalbu), dan keterampilan (daya pisik) yang diwujudkan dalam bentuk perbuatan. Dengan kata lain, kompetensi merupakan perpaduan dari penguasaan pengetahuan, keterampilan, nilai dan sikap yang direfleksikan dalam kebiasaan berpikir dan bertindak dalam melaksanakan tugas/pekerjaannya. Jadi, kompetensi adalah seperangkat pengetahuan,

\footnotetext{
${ }^{2}$ Wina Sanjaya. Kurikulum dan Pembelajaran. Jakarta: Kecana Media Group. 2008. Hlm. 7.

${ }^{3}$ Undang-undang Guru dan Dosen No 14 Tahun 2005.
} 
FITR AH Jurnal Kajian Ilmu-ilmu Keislaman

Vol. 03 No. 1 Juli 2017

keterampilan dan perilaku yang harus dimiliki, dihayati dan dikuasai oleh guru untuk dapat melaksanakan tugas-tugas profesionalnya.

Rumusan kompetensi di atas mengandung tiga aspek (1) kemampuan, pengetahuan, kecakapan, sikap, sifat, pemahan, apresiasi dan harapan yang menjadi ciri karakteristik seseorang dalam menjalakan tugas. Aspek ini menunjuk pada kompetensi sebgai gambaran substansi/materi ideal yang seharusnya dikuasai atau dipersayaratkan untuk dikusai atau dipersyaratkan untuk dikuasai oleh guru dalam menjalankan pekerjaannya. Dengan demikian seseorang dapat dipersiapkan atau belajar untuk menguasai kompetensi tertentu sebagai bekal ia bekerja secara profesional; (2) ciri dan karakteritik kompetensi yang digambarkan dalam aspek pertama tampil nyata (maniseft) dalam tindakan, tingkah laku dan unjuk kerjanya. Aspek ini merunjuk pada kompetensi sebagai gambaran unjuk kerja nyata yang tamapk dalam kualitas pola pikir, sikp dan tindakan seseorang dalam menjalankan pekerjaan secara piawai.

Perubahan peningkatan status guru menjadi tenaga profesional, tentunya kompetensi merupakan langakah penting yang perlu ditingkatkan. Kompetensi intelektual merupakan berbagai perangkat pengetahuan dalam diri individu, diperlukan untuk menunjang berbagai aspek unjuk kerja sebagai guru profesional. Hal ini, dapat digali dengan program peningkatan kualiatas diri dari pemerintah. Sedangkan kompetensi fisik dan individu, berkaitan erat dengan perangakat perilaku yang berhubungan denagn kemampuan individu dalam mewujudkan dirinya sebagai pribadi yang mandiri untuk melakukan transformasi diri, identitas diri dan pemahaman diri. Sebagai tenaga pendidik kompetensi guru dan dosen berbeda. Kompetensi guru terfokus pada kemampuan medidik. Sementara itu, kompetensi dosen mencakup kemampuan mendidik, dan mengabdi pada masyarakat.

Islam memandang profesi sebagai upaya fisik dan kegiatan berfikir yang dilakukan sessorang untuk menghasilkan kualitas. Profesi mengandung tiga unsur tentang upaya fisik, upaya intelektual dan unsur kesunguhan. Islam memuliakan orang yang memiliki ilmu pengetahuan yang profesional sebagaimana Allah menjelaskan dalam surat Al-Mujadilah ayat 11 sebagai berikut.

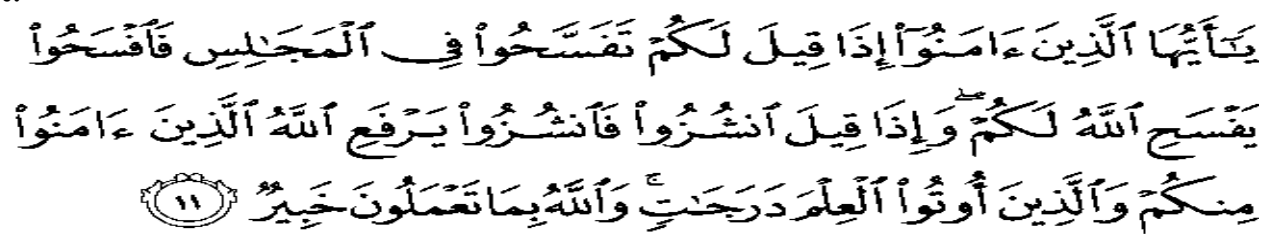


Artinya : Hai orang-orang beriman apabila kamu dikatakan kepadamu: "Berlapang-lapanglah dalam majlis", Maka lapangkanlah niscaya Allah akan memberi kelapangan untukmu. dan apabila dikatakan: "Berdirilah kamu", Maka berdirilah, niscaya Allah akan meninggikan orang-orang yang beriman di antaramu dan orang-orang yang diberi ilmu pengetahuan beberapa derajat. dan Allah Maha mengetahui apa yang kamu kerjakan. (Q.S.58.11) ${ }^{4}$

Berdasarkan tuntutan Undang-undang Guru dan dosen, serta standar pendidikan Nasional masih perlu dipertanyakan sejauhmana pendekatan keterampilan dasar mengajar calon guru Pendidikan Agama Islam mampu mempersiapkan dan melaksanakan, serta meintegrasikan nilai - nilai Islami secara lebih profesional selama praktek latihan terbimbing dan di Sekolah / Madrasah tempat praktek. Jawabannya adalah bahwa pencapaian tersebut masih jauh dari harapan. Hal ini dapat dibuktikan bahwa lemahnya calon guru melakukan Peraktek Pengalaman Lapangan (PPL). Muchtar Buchari menilai guru pendidikan Agama masih gagal. Kegagalan ini karena praktek Pendidikan Agama Islam yang hanya berorientasi pada aspek pengetahuan (kognitif) daripada pertumbuhan kesadaran nilai-nilai Islam, dan mengabaikan pembinaan aspek afektif dan psikomotor. Guru PAI kurang berupaya mengunakan berbagai strategi dan metode yang mungkin bisa dipakai untuk Pendidikan Agama, sehingga pembelajaran cenderung monoton. Kondisi ini mengakibatkan terjadinya kesenjangan antara pengetahuan dan pengamalan. Solusi dan tawaran diajukan suapaya memahami keterampilan dasar mengajar atau Microteaching dengan baik dan benar.

\section{Micro Teaching}

\section{Sejarah Singkat Microteaching}

Keterampilan dasar mengajar atau Microteaching pada awalnya dikembangkan di Amerika Serikat "The idea was development at Stanford University in 1963 (Allen and Ryan 1963). Pada tahun 1971 direkomendasikan pada The second Sub-Regional Workhop on Teacher Education yang dipopulerkan di Bangkok, Malaysia dan Filipina.

Pada tahun 1977 diperkenalkan di beberapa perguruan tinggi seperti IKIP Yokyakarta, IKIP Bandung, IKIP Ujung Pandang dan Universitas Kristen Satyawacana. Hasil seminar merekomendasikan bahwa keterampilan dasar

\footnotetext{
${ }^{4}$ Al-Quranul Karim
} 
FITR AH Jurnal Kajian Ilmu-ilmu Keislaman

Vol. 03 No. 1 Juli 2017

mengajar atau microteaching dimasukkan salah satu mata kuliah wajib pada Fakultas keguruan.

Keterampilan dasar mengajar (Microteaching) merupakan salah satu pendekatan untuk mempersiapkan dan meningkatkan kemampuan keprofesonalan mengajar secara terbimbing. Keterampilan dasar mengajar ini, dilatihkan secara sederhana, terbimbing, terkontrol, berulang-ulang, dengan mengunakan minimal ada 8 keterampilan dasar mengajar sesuai dengan kebutuhan sehingga tuntas (mastery learning), dibimbing oleh dosen pengampu mata kuliah Microteaching Berdasarkan solusi yang ditawarkan di atas, maka perlu disusun buku panduan Microteaching dan Praktek Pengalaman Lapangan bagi calon guru Pendidikan Agama Islam yang berintegrasi dengan nilai-nilai Islami, buku ini diharaapkan berguna untuk pedoman pembelajaran Microteaching dan dipakaikan PPL di sekolah / Madrasah.

\section{Model Pembelajaran Microteaching}

Model merupakan suatu yang mengambarkan adanya pola pikir kongkrit. Dalam perspektif penelitian, Bisri mengemukakan bahwa model adalah gambaran atau peragaan sederhana dari suatu realitas, yang sbenarnya realitas itu abstrak dan rumit. Model berfungsi sebgai penyederhanaan realitas, sehingga dapat digambarkan dan dijelaskan secara sederhana, ringkas dan mudah dipahami.

Menurut Kamus Basar Bahasa Indonesia (KBBI) model adalah pola (contoh, acuan, ragam dan sebagainya) dari sesuatu yang akan dibuat atau dihasilkan. Dengan demikian model dapat diartikan sebagai acuan yang menjadi dasar atau rujukan dari hal tertentu.

Dimyati dan Mudjiono menyatakan bahwa pembelajaran adalah kegiatan guru secara terprogram dalam desain instruksional, untuk membuat peserta didik belajar secara aktif yang menekankan pada penyediaan sumber belajar. Menurut Undang-Undang Nomor 20 Tahun 2003 tentang Sisdiknas adalah proses interaksi peserta didik dengan pendidik dan sumber belajar pada suatu lingkungan belajar.

Model pembelajaran adalah suatu perencanaan atau suatu pola yang digunakan sebagai pedoman dalam merencanakan pembelajaran di kelas dalam bentuk tutorial dan untuk menentukan perangkat-perangkat kurikulum 
termasuk di dalamnya buku-buku, film, komputer, kurikulum dan lain-lain ${ }^{5}$. Lebih lanjut Joyce menyatakan bahwa setiap model pembelajaran mengarahkan kita ke dalam mendisain pembelajaran untuk membantu peserta didik sedemikian rupa sehingga tujuan pembelajaran tercapai ${ }^{6}$.

Soekamto menjelaskan bahwa model pembelajaran adalah kerangka konseptual yang melukiskan prosedur yang sistematis dalam mengorganisasikan pengalaman belajar untuk mencapai tujuan belajar tertentu, dan berfungsi sebagai pedoman bagi perancang pembelajaran dan para pengajar dalam merencanakan aktivitas belajar mengajar.

Model pembelajaran mempunyai empat ciri. Empat ciri tersebut adalah: 1) rasional teoritis logis yang disusun oleh para pencipta atau pengembangnya, 2) landasan pemikiran tentang apa dan bagaimana peserta didik belajar (tujuan pembelajaran yang akan dicapai), 3) tingkah laku mengajar yang diperlukan agar model tersebut dapat dilaksanakan dengan berhasil, dan 4) lingkungan belajar yang diperlukan agar tujuan pembelajaran dapat tercapai.

Menurut Joyce dan Weil ${ }^{7}$ suatu model pembelajaran harus didukung oleh lima komponen, yang meliputi; sintak, sistem sosial, prinsip-prinsip reaksi, sistem pendukung dan efek instruksional dan pengiring. Menurut Arend ${ }^{8}$ model pembelajaran senada dengan Joyce dan Weil. Unsur-unsur model pembelajaran terdiri dari :

1. Sintak adalah urutan atau tahapan aktivitas yang akan dilakukan oleh dosen dan mahasiswa. Sintak dari suatu model pembelajaran adalah pola yang menggambarkan urutan alur tahap-tahap keseluruhan yang pada umumnya disertai dengan serangkaian kegiatan pembelajaran. Sintak setiap model pembelajaran relatif memiliki komponen-komponen yang sama, meliputi kegiatan awal/pendahuluan yang ditujukan untuk menarik perhatian peserta didik dan memotivasi peserta didik agar terlibat aktif dalam pembelajaran, kegiatan inti dan diakhiri dengan kegiatan menutup atau mengakhiri pembelajaran.

2. Sistem sosial merupakan gambaran tentang peranan dan hubungan antara pendidik (Dosen) dan peserta didik (mahasiswa ) serta aturan-aturan yang

\footnotetext{
${ }^{5}$ Bruce Joyce. Models Of Teaching-Second Edition. America : United State of America. 1992. Hlm. 4.

${ }^{6}$ Ibid.

${ }^{7}$ Bruce Joyce. Models of Teaching...Hlm. 4.

${ }^{8}$ Arend, Richard.. Clasroom Instructional Management. Newyork : The McGraw-Hill Company. 1997. Hlm. 7.
} 
FITR AH Jurnal Kajian Ilmu-ilmu Keislaman

Vol. 03 No. 1 Juli 2017

mengatur hubungan keduanya. Pada model tertentu adakalanya dosen memiliki peranan sentral. Dosen merupakan sumber belajar utama dan mahasiswa berperan sebagai pendengar pasif seperti halnya dengan modelmodel pembelajaran tradisional. Sementara pada model-model pembelajaran modern seperti pembelajaran aktif, kooperatif dan sebagainya, Dosen lebih banyak berperan sebagai fasilitator dan mediator dalam pembelajaran dan peserta didik (mahasiswa) yang terlibat aktif dalam pembelajaran.

3. Unsur model ketiga adalah prinsip reaksi. Prinsip reaksi adalah gambaran bagaimana dosen memberikan penghargaan (reinforcement) pada mahasiswa, menempatkan dan merespon apa yang dilakukan mahasiswa. Pemberian penghargaan maupun respon guru terhadap mahasiswa bisa berupa hadiah, nilai, kegiatan dan sebagainya. Misal pada model yang didesain untuk mengembangkan sikap mental mahasiswa untuk beraktifitas.

4. Unsur model pembelajaran keempat adalah sistem pendukung. Sistem pendukung adalah segala sarana, alat perangkat-perangkat yang diperlukan mendukung terlaksananya pembelajaran. Misalnya untuk menerapkan model pembelajaran yang menggambarkan keterampilan dan pengetahuan di kelas diperlukan penambahan perangkat yang menggambarkan keteranpilan dan pengetahuan tersebut.

5. Unsur model pembelajaran kelima adalah dampak instruksional (instructional effect) dan dampak pengiring (nurturant effect) yang diperoleh mahasiswa. Dampak ini dibedakan atas dampak atau pengaruh langsung (direct) dan tidak langsung/pengiring (nurturant). Dalam pembelajaran, hasilnya dapat dipengaruhi langsung oleh program-program atau kegiatan yang memang dirancang untuk mendapatkan hasil sesuai yang ditetapkan, namun bisa juga hasil yang didapat tidak direncanakan, namun merupakan dampak penyerta (nurturant effect).

Berdasarkan uraian tentang materi model pembelajaran di atas, maka dapat disimpulkan bahwa model pembelajaran adalah bentuk atau contoh yang tersusun secara sitimatis yang digunakan untuk membantu mahasiswa memperoleh hasil belajar yang baik. Kelima komponen ini akan digunakan untuk mekonstruksi pengembangan atau penciptaan suatu model pembelajaran. 


\section{Karakteristik Microteaching}

Ciri hkas Keterampilan dasar mengajar (microteaching) dalam pembelajaran adalah dalam bentuk "penyederhanaan". Bersal dari micro dan teaching yaitu suasana kondisi pembelajaran yang disederhanakan, atau dirancang dalam bentuk kecil. Bentuk pembelajaran penyederhanaan ini dianggap sangat penting, karena jika keterampilan dasar mengajar ini dilaksanakan dalam bentuk kecil ini sukses, maka pembelajaran yang lebih luas dapat diatasi dengan baik dan sebalinya.

Untuk mengilustrasikan pembelajaran keterampilan dasar mengajar dalam bentuk micro atau penyederhanaan, namun tetap memperhatikan aspek pembelajaran yang sebenarnya ( real teaching) hanya saja praktek keterampilan dasar mengajar dalam bentuk microteaching tidak dilakukan di kelas yang sebenarnya (not real classroom teaching).

Tabel 1 Perbandingan Pembelajaran Biasa dan Microteahing

\begin{tabular}{|c|c|c|}
\hline No & Pembelajaran Biasa & Pembelajaran Penyederhanaan \\
\hline 1 & Waktu pembelajaran 40 - 45 menit & Waktu pembelajaran 15-20 menit \\
\hline 2 & Jumlah pesidik sekitar 30-35 orang & Jumlah pesdik sekitar $10-15$ orang \\
\hline 3 & Materi pembelajaran lebih luas & Materi pembelajaran dibatasi \\
\hline 4 & $\begin{array}{l}\text { Keterampilan dasar mengajar yang } \\
\text { digunakan terintegrasi }\end{array}$ & $\begin{array}{l}\text { Keterampilan dasar mengajar } \\
\text { terisolasi }\end{array}$ \\
\hline 5 & Praktek dilaksanakan di kelas & Praktek di labor atau di kelas bisa \\
\hline 6 & Diajar peserta didik benaran & Diajar teman sebaya sebagai pesdik \\
\hline 7 & $\begin{array}{l}\text { Pembelajaran sebenarnya (real } \\
\text { teaching) }\end{array}$ & $\begin{array}{l}\text { Tidak di kls sebenarnya (not real } \\
\text { classroom teaching) }\end{array}$ \\
\hline
\end{tabular}

\section{Jenis Microteaching}

Ada beberapa jenis Microteaching ${ }^{9}$ mengajar yang dapat dipraktekan pada dan harus dikuasai, dilatihkan, dan dikembangkan oleh calon guru profesional antara lain:

a. Stimulus Variation, stimulus pembelajaran disajikan secara bervariasi, seperti variasi dalam mengunakan metode, media, gaya mengajar, suara, komunikasi, pembelajaran, dan lain sebaginya.

${ }^{9}$ Dwight Allen and Kevin Ryan, Microteaching. University of Massachusetts and University of Chicago, by Addson Wesley Publishing Company,Inc. 1969. Hlm. 15. 
FITR AH Jurnal Kajian Ilmu-ilmu Keislaman

Vol. 03 No. 1 Juli 2017

b. Set Induction, keterampilan membuka pembelajaran, yaitu upaya yang dilakukan oleh guru untuk menumbuhkan perehatian dan motivasi belajar peserta didik.

c. Closure, keterampilan menutup pembelajaran, yaitu upaya yang dilakukan oleh guru untuk mengakhiri pembelajaran agar peserta didik memperoleh pengalaman belajar secara utuh dari hasil pembelajaran yang telah dilakukan.

d. Silence and nonverbal cues, kegiatan diam sejenak, yaitu suatu upaya untuk menciptakan suasana hening dari aktifitas selama beberapa detik dengan maksud untuk menumbuhkan dan meningkatkan perhatian dan dan partisipasi peserta didik dalam pembelajaran.

e. Reinforcement of student partisipation, memberi penguatan, yaitu kegiatan memberikan respon oleh guru terhadap aktifitas belajar peserta didi. Tujuan pemberian penguatan antara lain untuk lebih meningkatkan motivasi belajar.

f. Fluence in asking questions, keterampilan mengemukakan pertanyaan, yaitu menggunakan pertanyaan-pertanyaan yang dapat mengaktifkan peserta didik belajar. Melalui pertanyaan yang bervariasi peserta didik dapat diransang untuk berfikir atau belajar dari cara yang sederhana menuju pada kegiatan belajar yang rumit dan mendalam.

g. Frobing questions, keterampilan pertanyaan pelacak, yaitu menggunakan pertanyaan pertanyaan lanjutan untuk memperdalam atau untuk lebih menggali terhadap jawaban yang diperlukan dari peserta didik.

h. Higher order questions, pertanyaan pelacak, yaitu pertanyaan tindak lanjut yang diajukan kepada peserta didik untuk meningkatkan kemampuan belajar secara lebih analitis dan komprehensif.

i. Divergent questions, pertanyaan yang berbeda, yaitu keterampilan untuk mengemukakan berbagai bentuk pertanyaan yang berbeda-beda terhadap suatu permasalahan yang ingin ditanyakan'

j. Ilustration and use of example, keterampilan membuat ilustrasi dan contohcontoh, yaitu sebagai upaya untuk lebih memperjelas pembehasan untuk lebih mempermudah pemahaman peserta didik terhadap materi yang sedang dijelaskan. 
k. Lecturing, keterampilan menjelaskan, yaitu suatu keterampilan untuk mekomunikasikan materi pembelajaran kepada peserta didik secara jelas, sehingga peserta didik dapat memahaminya secara jelas.

1. Completeness of comunication, keterampilan berkomunikasi, yaitu kemampuan melakukan komunikasi dengan lancar baik komunikasi verbal maupun nonverbal.

\section{Prosedur Pelaksanaan Microteaching.}

Meningkatkan kualitas guru dalam pembelajaran melalui langkahlangkah sebagai berikut, pertama tahap persiapan pembelajaran, pada tahap ini diawali dengan memahami teori pembelajaran. Sebagaimana di ungkap dalam orang orang bijak antara lain, "tidak ada peraktek yang baik tanpa ditunjang dengan teori", penguasaan teori saja belum cukup kalau tidak disertai kemampuan praktis". Dengan demikian antara teori dengan praktek saling melengkapi.

Nana Syaodih mengemukakan bahwa teori penting dikuasai karena teori memiliki tiga fungsi utama, yaitu mendeskripsikan, menjelaskan, dan memprediksikan. Kaitanya dengan keterampilan dasar mengajar (microteaching) adalah pertama, keterampilan dasar mengajar berupa perencanaan; kedua berkenaan dengan aspek-aspek segala hal yang berkenaan dengan keterampilan dasar mengajar; dan ketiga merencanakan kegiatan-kegiatan yang harus dilakukan sesuai dengan keterampilan dasar mengajar.

Perencanaan yang harus dipersiapkan adalah berkaitan dengan mendesain perencanaan pembelajaran. Kegiatan ini diawali mengkaji silabus dan materi yang akan diajarkan. Kemudian dilanjutkan dengan pembagikan kelompok sesuai dengan ketentuan yang berlaku.

Kegiatan inti adalah kegiatan pokok untuk mempelajari materi yang telah direncanakan. Kegiatan pembelajaran adalah proses interaksi antara peserta didik dengan lingkungan pembelajaran untuk mencapai tujuan dan kompetensi pembelajaran. Unsur-unsur kegiatan inti adalah :

1. Iinteraktif yaitu proses komunikasi antara peserta didik dengan guru, antar peserta didik, guru, sumber belajar lainnya.

2. Inspiratif, yaitu melalui pembelajaran harus mendorong peserta didik secara aktif, inovatif menemukan ide-ide baru dan mampu menciptakan dan memecahkan masalah. 
FITR AH Jurnal Kajian Ilmu-ilmu Keislaman

Vol. 03 No. 1 Juli 2017

3. Menyenangkan, yaitu menciptakan suasana menyejukan, sehingga peserta didik mampu berkreasi.

4. Menantang, yaitu untuk mengugah peserta didik aktif mencari informasi pembelajaran yang dibutuhkan.

5. Memotivasi peserta didik, yaitu menumbuhkan semangat belajar secara aktif.

6. Prakarsa, yaitu kesempatan berinisiatif dalam melakukan berbagai aktifitas baik di luar, maupun di dalam kelas.

7. Kreatifitas, yaitu pengembangan kegiatan sesuai dengan bakat dan minat.

8. Kemandirian, yaitu aktifitas pembelajaran mampu mefasilitasi peserta didik untuk mengembangkan sikap percaya diri

Dadang Sukirman ${ }^{10}$ merujuk pandangan konstruktivisme kegiatan inti pembelajaran meliputi antara lain, Constructivation, inquiri, questioning, learning komoniti, modeling, and reflektion.

Kegiatan penutup / pembelajaran, kegiatan untuk mengakiri pembelajaran dalam bentuk diskusi umpan balik dan program tindak lanjut. Untuk meningkatkan kualitas pembelajaran keterampilan dasar mengajar yang optimal dilatihkan secara berulang-ulang, bagian demi bagian.

\section{Microteaching yang terintegrasi dengan nilai-nilai Islami}

Konsep integrasi adalah suatu upaya menggabungkan atau menyatukan sesuatu dengan sesuatu yang lain sehingga menjadi sebuah bentuk kombinasi antara kedua hal tersebut, yang mana yang satu menjadi bagian dari yang lain. Nilai adalah suatu keyakinan yang membuat seseorang bertindak atas dasar pilihannya. Nilai juga hampir sama dengan akhlak, yaitu fitrah tauhidullah yang dikembangkan dan diiplementasikan dalam peribadi seseorang untuk mencapai akhlak mulia demi kebahagiaan hidup di dunia dan di ahkirat.

Nilai-nilai Islami adalah aturan atau norma yang diilhami Al-quran dan sunnah yang penekanannya pada keseimbangan dan kesejahteraan hidup duniawi dan ukhrawi menjadi landasan ideal yang hendak dikembangkan atau dibudayakan dalam prbadi muslaim melalui peraktek keterampilan dasar mengajar secara terbimbing. Ditinjau dari segi sumbernya nilai-nilai islami itu : Pertama nilai Illahi, yaitu nilai yang sumbernya dari Al-Quran dan Sunnah, nilai Illahi dalam aspek teologi (kaedah keimanan) tidak akan pernah mengalami

\footnotetext{
${ }^{10}$ Dadang Sukirman, 2006, Pembelajaran Micro, Bandung: UPI Press. 2006. Hlm. 64.
} 
perubahan dan tidak berkecendrungan untuk berubah atau mengikuti selera hawa nafsu manusia. Sedangkan aspek alamiahnya dapat mengalami perubahan sesuai dengan perkembangan zaman dan lingkungannya. Kedua nilai Insani, yaitu nilai yang tumbuh dan berkembang atas kesepakatan manusia. Nilai insani ini akan terus berkembang ke arah yang lebih maju dan lebih tinggi. Nilai ini bersumber dari ra'yu, adat istiadat dan kenyataan alam. Sedangkan nilai-nilai religius adalah nilai yang mendasarinya berorientasi pada aspek halal dan haram atau pahala dan dosa.

Landasan nilai-nilai islami adalah Al-Quran dan Sunnah. Al- Quran adalah kalam Allah yang diturunkan kepada nabi Muhammad melalui malaikat jibril dengan lafaz bahasa arab dan makna hakiki untuk menjadi hujjah bagi Rasulullah atas kerasulannya dan menjadi pedoman bagi manusia menunjukannya serta beribadah membacanya. Al-Quran sebagai sumber utama dijelaskan Allah Surat An-Nahl :ayat 16 :

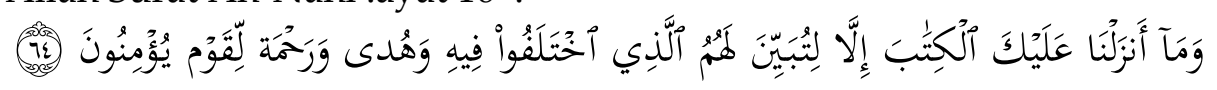

Artinya : Dan Kami tidak menurunkan kepadamu Al-Kitab (Al-Quran) melainkan agar kamu menjelaskan kepada mereka apa yang mereka perselisihkan itu dan menjadi petunjuk dan rahmat bagi kaum yang beriman (Q,S An-Nahl 64).

Surat As-Shad ayat $29:$

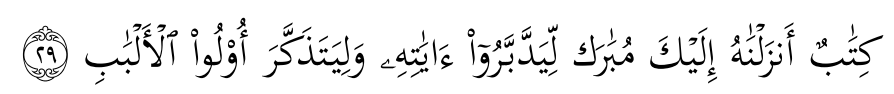

Artinya :Ini adalah sebuah kitab yang kami turunkan kepadamu penuh dengan berkah supaya mereka memperhatikan ayat-ayatNya dan supaya mendapat pelajaran orang-orang mempunyai fikiran (Q.S. As-Shad ayat 29).

Sunnah sebagai sumber kedua dapat dijadikan dasar nilai-nilai islami Allah menjelaskan dalam Al-Quran bahwa Muhammad dijadikan contoh teladan yang baik sebagaimana firman Allah dalam surat Al-Ahzab ayat 21

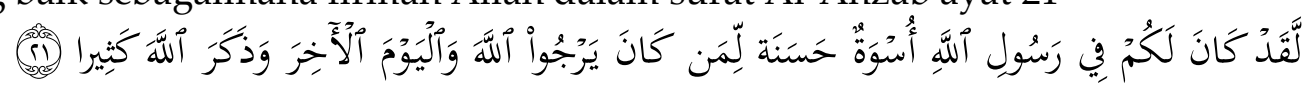

Artinya : Sesungguhnya telah ada pada diri Rasulullah itu suri teladan yang baik bagimu, yaitu bagi orang yang mengharap rahmat Allah dan kedatangan hari kiamat dan dia banyak menyebut Allah (Q.S AlAhzab ayat 21) 
FITR AH Jurnal Kajian Ilmu-ilmu Keislaman

Vol. 03 No. 1 Juli 2017

Rasulullah menjadi contoh teladan dan apa yang dibawa beliau menjadi rahmat bagi semesta alam, sebagaimana firman Allah dalam surat Al-An-Biya' ayat 107

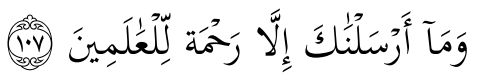

Artinya: Dan dia lah kami menutus kamu melainkan untuk menjadi rahmat bagi semesta alam (Q.S Al-Anbiy; 107)

Konsep integrasi pada keterampilan dasar mengajar yang terintegrasi dengan nilai-nilai Islami adalah suatu upaya menggabungkan atau menyatukan konsep keterampilan dasar mengajar ( teaching Skill ) yang berlaku umum dengan nuansa nilai-nilai keislaman yang dilakukan dalam praktek latihan terbimbing dalam mata kuliah Microteaching, pada program studi Pendidikan Agama Islam .

Meintegrasikan nilai-nilai pendidikan Islam dalam keterampilan dasar mengajar (teaching skills) secara terbimbing pada dasarnya merupakan bentukbentuk perilaku atau kemampuan yang bersifat khusus atau profesional dan mendasar (most spesific instructional behaviours) dimiliki oleh mahasiswa sebagai calon guru pendidikan agama islam, merupakan modal dasar untuk melaksanakan tugas-tugas mulia secara terbimbing dalam meraih guru yang profesional dan Islami.

Keterampilan dasar mengajar yang penulis bahas yakni 8 keterampilan dasar mengajar atau microteaching sebagai berikut :

\section{Membuka (Set Induction).}

Keterampilan membuka pelajaran merupakan komponen pertama dilatihkan dan harus dilakukan secara profesional. Dalam keterampilan membuka pelajaran, calon guru memberikan pengantar atau pengarahan terhadap materi yang akan diajarkan pada teman seprofesi agar siap mental dan tertarik untuk mengikutinya. Keterampilan membuka pelajaran dalam istilah lain dikenal dengan set induction, yang artinya usaha atau kegiatan yang dilakukan oleh calon guru dalam kegiatan pembelajaran untuk menciptakan prokondisi bagi mahasiswa agar mental maupun perhatian terpusat pada apa yang akan dipelajarinya sehingga usaha yang tersebut akan memberikan efek yang positif terhadap kegiatan belajar. Keterampilan membuka antara lain :

a. Menghubungkan materi yang telah diajarkan dengan materi yang akan diajarkan. 
b. Menyampaikan tujuan yang akan dicapai dan garis besar materi yang akan diajarkan.

c. Menyampaikan langkah-langkah kegiatan pembelajaran dan tugas-tugas yang harus diselesaikan untuk mencapai tujuan.

d. Memanfaatkan media dan sumber belajar sesuai dengan materi yang akan diajarkan.

e. Mengajukan pertanyaan, baik untuk mengetahui pemahaman peserta didik terhadap pelajaran yang lalu, dan menjajaki kemampuan awal yang berkaitan dengan bahan yang akan dipelajari.

Keterampilan membuka pelajaran merupakan kunci dari seluruh proses pembelajaran. Sebab jika seorang calon guru pada awal pembelajaran tidak mampu menarik perhatian peserta didik, maka tujuan pembelajaran tidak akan tercapai dengan baik. Siasat membuka pelajaran dilakukan saat pengenalan konsep baru. Kegiatan membuka pelajaran tidak hanya dilakukan oleh calon guru pada awal pelajaran, tetapi juga pada setiap awal kegiatan inti pelajaran yang diberikan selama aktifitas pembelajaran berlangsung. Ini dapat dilakukan dengan cara menyampaikan tujuan yang akan dicapai, menarik perhatian peserta didik, memberi acuan, dan membuat kaitan antara materi pelajaran yang akan dikuasai oleh peserta didik dengan bahan yang akan diajarkan.

Agar kegiatan keterampilan dasar mengajar membuka pelajaran dapat dilakukan oleh calon guru secara efektif dan memiliki nuansa keislaman, maka diperlukan wawasan pendidik tentang menarik minat peserta didik mengikuti proses pembelajaran, membangkitkan rasa ingin tahu, dan memberikan motivasi yang tinggi.

"Islam memberikan petunjuk bahwa setiap memulai aktifitas atau kegiatan yang dilakukan didahului dengan baca "Basmallah" sebagimana firman Allah dalam surat An-Namal ayat 30, sebagai berikut :

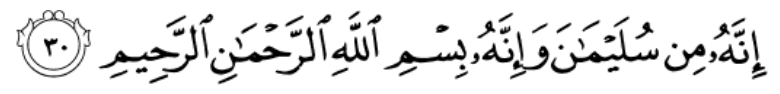

Artinya : Sesungguhnya surat itu, dari Sulaiman dan Sesungguhnya (isi)nya: "Dengan menyebut nama Allah yang Maha Pemurah lagi Maha Penyayang.

Ayat ini memberi petunjuk bahwa apa saja aktifitas yang dilakukan mulai dengan niat yang baik dan baca basmallah, apalagi melakukan praktek keterampilan dasar mengajar.. Nabi Pada surat Thaha ayat 25 memberi petunjuk 
FITR AH Jurnal Kajian Ilmu-ilmu Keislaman

Vol. 03 No. 1 Juli 2017

bahwa Nabi Musa minta kepada Allah supaya segala urusannya diserahkan kepada Allah :

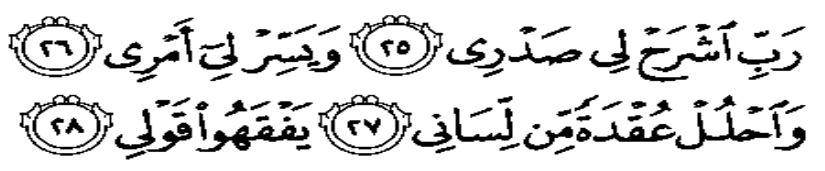

Artinya: Berkata Musa, ya Tuhan lapangkanlah untukku dadaku, dan mudahkanlah untukku urusanku, dan lepaskanlah kekakuan dari lidahku, supaya mereka mengerti perkataanku (Q.S Thaaha, 20:25-28).

\section{Mengelola Kelas (Classroom Management)}

Keterampilan mengelola kelas merupakan keterampilan guru untuk menciptakan dan memelihara kondisi belajar yang optimal dan mengembalikan ke ondisi yang optimal jika terjadi gangguan, baik dengan cara mendisiplinkan ataupun melakukan kegiatan remedial. Komponen Keterampilan Mendesain Kelas adalah:

1) Kehangatan dan keantusiasan

2) Penggunaan bahan yang menantang akan meningkatkan gairah belajar peserta didik.

3) Perlu dipertimbangkan penggunaan variasi media, gaya mengajar, dan pola interaksi.

4) Diperlukan keluwesan tingkah laku guru dalam mengubah strategi mengajarnya untuk mencegah gangguan yang timbul.

5) Penekanan hal yang positif dan menghindari pemusatan perhatian peserta didik pada hal negatif.

6) Mendorong peserta didik untuk mengembangkan disiplin diri sendiri dengan cara memberi contoh dalam perbuatan guru seharihari.

Keterampilan mengelola kelas dibedakan menjadi dua, yaitu keterampilan yang berkaitan dengan penciptaan dan pemeliharaan kondisi belajar yang optimal. Dalam rangka melakukan penciptaan belajar yang optimal, maka perlu:

1). Menunjukkan sikap yang tanggap: melalui perbuatan sikap tanggap ini peserta didik merasakan bahwa "guru hadir bersama mereka" dan " tahu apa yang mereka perbuat".

2). Membagi perhatian; pengelolaan kelas yang efektif ditandai dengan pembagian perhatian yang efektif pula. Perbuatan membagi perhatian 
dapat dikerjakan secara visual dan verbal. Memusatkan perhatian kelompok dengan cara:

1. Memberi petunjuk-petunjuk yang jelas.

2. Menegur: teguran verbal yang efektif harus memenuhi persyaratan sebagai berikut: (1) tegas, jelas tertuju kepada peserta didik yang mengganggu dan tingkah laku yang harus dihentikan (2) menghindari peringatan yang kasar atau yang mengandung penghinaan (3) menghindari ocehan berkepanjangan.

3. memberi penguatan: pemberian penguatan dapat dilakukan kepada peserta didik yang suka menggangu jika pada suatu saat di tertangkap melkukan perbuatan yang positif. Dapat pula kepada siswa yang bertingkah laku yang wajar sebagai contoh.

Keterampilan yang berkaitan dengan pengembalian kondisi belajar yang optimal. Keterampilan ini berkaitan dengan respons guru terhadap gangguan peserta didik yang berkelanjutan dengan maksud agar guru dapat mengadakan tindakan remedial untuk mengembalikan kondisi belajar yang optimal.

\section{Mengadakan Variasi (Variation Stimulus)}

Kejenuhan atau kebosanan yang dialami dalam kegiatan proses pembelajaran sering terjadi. Namun dengan harapan bervariasinya proses pembelajaran yang diberikan akan membawa cakrawala kecerahan bagi peserta didik di lapangan. Variasi stimulus itu adalah, suatu kegiatan guru dalam kontek proses intreraksi pembelajaran yang ditujukan untuk mengatasi kebosanan peserta didik, sehingga dalam proses situasi pembelajaran senantiasa menujukan ketekunan dan penuh partisipasi. Tujuan proses pembelajaran variasi intinya adalah menumbuh kembangkan perhatian dan minat peserta didik agar belajar lebih baik. Sedangkan manfaat keterampilan variasi dalam proses pembelajaran adalah

a. Menumbuhkan pertahatian peserta didik.

b. Melibatkan peserta didik berpartisipasi dalam berbagai kegiatan proses pembelajaran.

c. Dngan bervariasinya cara guru menyampaikan proses pembelajaran akan membentuk sikap positif bagi peserta didik terhadap guru.

d. Dapat menanggapi rasa ingin tahu dan ingin menyelidiki peserta didik. 
FITR AH Jurnal Kajian Ilmu-ilmu Keislaman

Vol. 03 No. 1 Juli 2017

e. Melayani keinginnan dan pola belajar para peserta didik yang berbedabeda.

Keterampilan variasi yang dapat dilakukan dalam proses pembelajaran terbagi kepada tiga kelomok besar antara lain variasi dalam gaya guru mengajar, variasi dalam pola inrtaksi guru dengan peserta didik, dan variasi dalam menggunakan media dan alat-alat pembelajaran.

Variasi dalam gaya guru yang profesional harus hidup dan antusias (teacher liveliness) menarik minat belajar peserta didik. Bisa dilakukan dengan suara dan isyarat-isyarat non verbal seperti pandangan mata, ekpresi roman muka, gerak gerik tangan, badan. Selain itu juga ada syarat-syarat lain yang dikenal axtra-verbal, yaitu informasi warna, bunyi-bunyian paling tidak guru harus mempergunakan variasi melalui:

a. Suara guru (voice variations) tekanan tinggi-rendah, cepat-lambat.

b. Memusatkan perhatian peserta didik (verbal focussing) pada hal yang dianggap penting dapat dilakukan guru dengan kata-kata seperti, perahian baik-baik, awas, sekaligus dilakukan dengan gerakan tangan.

c. Mengadakan diam sejenak (silence) pada saat yang tepat membuat pembicaraan guru lebih jelas, karena ini berfungsi sebagai koma, titik, atau tanda seru yang membagi pelajaran dalam kolompok-kelompok kecil.

d. Intonasi dan bunyi-bunyian lain (extra-verbal cues) seperti guru menanggapi pekerjaan peserta didik dengan kata-kata, aah, eeh, hmm, wah, pintar sekali disampaikan sesuai dengan nada suara, dengan kata-kata ini membuat perasaan peserta didik lebih akrab.

e. Guru menguasai dengan kontak mata (eye contact), kalau ada kontak mata guru dengan peserta didik, kata-kata yang diucapkan guru terasa lebih meyakinkan dan memperkuat informasi. Sebaiknya guru menatap peserta didik secara keseluruhan, tidak diarahkan ke arah tertentu saja seperti yang duduk di depan saja, tengah sehingga yang duduk di samping tidak dilihat.

f. Ekspresi roman muka (facial expression), ekpressi roman wajah guru perlu ceria dan bahkan ini sangat penting dalam berkomunikasi dengan peserta didik. Wajah yang punya ekspresi akan memberi kesan tersendiri bagi peserta didik, sebaliknya wajah yang seram akan membosankan bagi peserta didik. Semuanya ini diikuti dengan tersenyum, mengerutklan bibir, mengedipkan mata dan sebaginya. 
g. Gerak gerik tangan (gestures) variasi dengan gerakan tangan, mata, kepala, dan badan dapat memperkuat ekspresi guru, sebaliknya gerakan yang anaeh dapat mengganggu situasi perhatian dalam proses pembelajaran.

h. Tempat berdirinya guru di kelas (movement) variasi penggantian posisi guru di dalam kelas akan mendapat perhatian oleh peserta didik, seperti gerakan ke arah depan, belakang, kanan ke kiri dan sebagainya (tidak selalu duduk dalam kelas). Jika guru melakukan tanya jawab sebaiknya dekatilah pelan-pelan peserta didik. Kalau guru mendekati peserta didik mengandung arti yang sangat dalam bagi mereka.

i. Variasi dalam pola interaksi dan kegiatan peserta didik, hindari guru banyak bicara atau terlalu lama sehingga kehilangan perhatian dan minat peserta didik. Justru berikan pekerjaan lebih banyak kepada mereka, dalam bentuk mengarang, membaca buku, mengerjakan soal, diskusi, membuat laporan, membaca dalam hati, dan sebagainya.

j. Variasi dalam mengunakan media dan bahan pengajaran, Sebaiknya guru membuat skema di papan tulis atau dengan memekai media lain seperti rekaman, gambar, slides, in fokus, lap top, dan sebagainya, bisa juga dengan visual (dapat dilihat), audio (dapat didengar), dan tatile/motorik (dapat diraba)

Pada prinsipnya teknik dasar variasi dalam mengajar adalah :

1. Suara guru enak didengar.

2. Tidak banyak melihat ke jendela saat sedang mengajar.

3. Melihatkan kegembiraan dan semangat.

Mengunakan isyarat mata, tangan, kepala denga tepat. Hafal nama-nama peserta didik di kelas dan memanggil namanya saat diperlukan.

4. Variasikan peserta didik menjawab pertanyaan tidak orang tertentu saja.

5. Mengadakan selingan yang menyegarkan.

6. Mempertimbangkan prinsip hadiah dan hukuman.

Variasi dalam gaya mengajar guru dapat dilakukan antara lain, dalam bentuk, Pertama verbal (dengan menggunakan suara dan kata-kata yang diucapkan guru ) seperti (1) nada suara dan intonasi (Voice variation), (2) mengarahkan perhatian peserta didik (verbal focussing), (3) mengadakan pause/diam sebentar (pausing/silence), (4) isyarat-isyarat lisan lain (extra verbal cues). Kedua, Non Verbal (dengan isyarat/bahasa badan), mencakup (1) kontak pandangan mata (eye contact), (2) Ekpresi roman muka (facial 
FITR AH Jurnal Kajian Ilmu-ilmu Keislaman

Vol. 03 No. 1 Juli 2017

expressions), (3) gerak gerik tangan, kepala, badan (gestures), (4) posisi (tempat berdiri di kelas).

\section{Memberi Penguatan (Re-Inforcement)}

Pada umumnya penghargaan memberi pengaruh positif terhadap kehidupan manusia, karena dapat mendorong dan memperbaiki tingkah laku seseorang serta meningkatkan usahanya. Memang sudah merupakan fitrah manusia bahwa manusia ingin di hormati, dihargai, dipuji, dan disanjungsanjung, lemah lembut tentu saja semuanya ini dalam batas-batas yang wajar. The right men, in the right please (letakan sesuatu pada tempatnya), Allah s.w.t selalu mengingatkan kita didalam surat Ali Imran ayat 159:

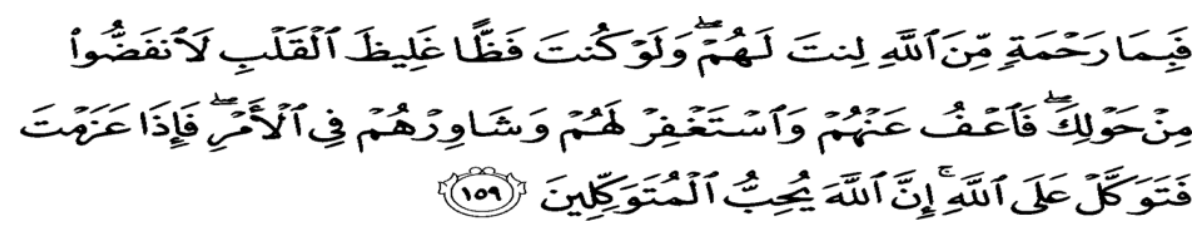

Artinya : Maka disebabkan rahmat dari Allah-lah kamu Berlaku lemah lembut terhadap mereka. Sekiranya kamu bersikap keras lagi berhati kasar, tentulah mereka menjauhkan diri dari sekelilingmu. karena itu ma'afkanlah mereka, mohonkanlah ampun bagi mereka, dan bermusyawaratlah dengan mereka dalam urusan itu[246]. kemudian apabila kamu telah membulatkan tekad, Maka bertawakkallah kepada Allah. Sesungguhnya Allah menyukai orang-orang yang bertawakkal kepada-Nya.

Kegiatan proses pembelajaran, pengharagaan mempunyai arti tersendiri. Semua pemghargaan ini tidak berujud materi, melainkan dalam bentuk kata-kata, senyuman, sebagaimana dalam perkataan Rasulullah bahwa "senyum itu adalah sedekah", anggukan, dan sentuhan. Pada dasarnya antara keterampilan memberi penguatan dengan keterampilan bertanya saling terkait satu sama lainnya.

Intisari dari penguatan adalah merespon terhadap suatu tingkah laku positif yang dapat meningkatkan kemungkinan berulangnya kembali tingkah laku tersebut. Penguatan tidak boleh dianggap sepele dan sembarangan, tetapi harus mendapat perhatian serius. Hal-hal yang harus diperhatikan dalam menggunakan keterampilan penguatan antara lain :

a) Hindari komentar negatif, jika peserta didik tidak mampu menjawab pertanyaan jangan mereka dibentak, di hina.

b) Kehangatan, artinya perlihatkan dalam gerakan, mimik, suara, anggukan yang serius. 
c) Kesunguhan, dilaksanakan dengan serius tidak basa-basi.

d) Bermakna, jika guru bertanya dan peserta didik menjawab, maka guru harus menjawab seperti bagus, tepat.

e) Perlu ada variasi, seperti anggukan, senyum, sentuhan, bagus, gerakan tangan.

Komponen Keterampilan Penguatan :

Pembelajaran penguatan memiliki peran yang sangat penting untuk meningkatkan proses dan hasil pembelajaran yang lebih memiliki makna dan bermutu. Pujian dan repon positif yang diberikan oleh guru kepada peserta didik yang telah menunukan prestasi, baik dalam bidang akademik maupun non-akademik, anak akan merasakan bahwa perbuatannya dihargai dan dengan demikian akan menjadi motivator untuk terus berusaha menunjukan prestasi terbaiknya. Pada perinsipnya keterampilan penguaran dapat dikelompokan kepada dua jenis, penguatan verbal dan penguatan non-verbal.

1. Penguatan Verbal, artinya berupa kata-kata, kalimat seperti saya senang, ya, dan sebaginya.

2. Panguatan Non Verval, berupa mimik, dan gerakan tubuh. Berupa, mimik dan gerakan tangan, dengan pendekatan, dan menggunakan sentuhan digosokgosok punggungnya. Melalui kegiatan menyenangkan seperti ditunjuk mereka menjadi ketua kelas. Menggunakan simbul atau benda, seperti anak disuruh mengerjakan PR di papan tulis, kemudian diberikan tanda betul, dan penguatan tak penuh seperti jawabanmu benar, tetapi perlu disempurnakan lagi.

\section{Bertanya (Questioning)}

Mengajukan pertanyaan dengan baik adalah mengajar yang baik. bertanya adalah membimbing peserta didik belajar". Hasil penelitian menunjukkan bahwa pada umumnya guru tidak berhasil menggunakan teknik bertanya yang efetif. Keterampilan bertanya menjadi penting jika dihubungkan dengan pendapat yang mengatakan "berpikir itu sendiri adalah bertanya.

Bertanya merupakan ucapan verbal yang meminta respons dari seseorang yang terkenal. Respons yang diberikan dapat berupa pengetahuan sampai dengan hal-hal yang merupakan stimulasi efetif yang mendorongkan kemampuan berpikir antara lain :

a. Merangsang kemampuan berpikir peserta didik. 
FITR AH Jurnal Kajian Ilmu-ilmu Keislaman

Vol. 03 No. 1 Juli 2017

b. Membantu peserta didik dalam belajar

c. Mengarahkan peserta didik pada tingkat interaksi belajar yang mandiri

d. Meningkatkan kemampuan berpikir siswa dari kemampuan berpikir tingkat rendah ketingkat yang lebih tinggi.

e. Membantu siswa dalam mencapai tujuan pelajaran yang dirumuskan.

Komponen-komponen yang termasuk dalam keterampilan dasar bertanya meliputi:

1) Pengungkapan pertanyaan secara jelas dan singkat

2) Pemberian acuan, Supaya siswa dapat menjawab dengan tepat, dalam mengajukan pertanyaan guru perlu memberikan informasi-informasi yang menjadi acuan prtanyaan.

3) Pemusatan kearah jawaban yang diminta: Pemusatan dapat dikerjakan dengan cara memberikan pertanyaan yang luas (terbuka) yang kemudian mengubahnya menjadi pertanyaan yang sempit.

4) Pemindahan giliran menjawab: pemindahan giliran menjawab dapat dikerjakan dengan cara meminta peserta didik yang berbeda untuk menjawab pertanyaan yang sama.

5) Penyebaran pertanyaan: untuk maksud tertentu guru dapat melemparkan pertanyaan keseluruh kelas, kepada peserta didik tertentu, atau menjabarkan respons pesera didik kepada peserta didik yang lain.

6) Pemberian waktu berfikir: dalam mengajukan pertanyaan guru harus berdiam diri sesaat sebelum menunjukkan peserta didik merespons pertanyaannya.

7) Pemberian tuntunan: bagi peserta didik yang mengalami kesukaran dalam menjawab pertanyaan, strategi pemberian tuntunan perlu dikerjakan. Strategi itu meliputi pengungkapan pertanyaan dengan bentuk atau cara yang lain, mengajukan pertanyaan lain yang lebih sederhana, atau mengulangi penjelsan-penjelasan sebelumnya.

Komponen-komponen yang termasuk kedalam keterampilan bertanya lanjutan adalah:

1) Pengubahan tuntunan tingkat kognitif pertanyaan: untuk pengembangan berfikir peserta didik perlu dilakukan pengubahan tuntutan tingkat kognitif pertanyaan.

2) Urutan pertanyaan: pertanyaan yang diajukan mempunyai urutan yang logis. 
3) Mengetahui sejauh mana kemampuan peserta didik yang berkaitan dengan jawaban yang dikemukakan, keterampilan melacak perlu dipunyai oleh guru. Melacak dapat dapat dikerjakan dengan meminta peserta didik untuk memberikan penjelasan tentang jawabannya, memberikan alasan, memberikan contoh yang relevan, dsb.

4) Keterampilan mendorong terjadinya interaksi antar peserta didik.

\section{Menjelaskan Pelajaran ( Expalining )}

Keterampilan memberi penjelasan adalah penyajian informasi secara lisan yang diorganisasi secara sitematis untuk menujukan adanya hubungan yang satu dengan yang lainnya. Ciri utama keterampilan penjelasan yaitu penyampaian informasi yang terencana dengan baik dan disajikan dengan benar, serta urutan yang cocok dan disesuaikan dengan tingkat pengetahuan peserta didik.

Sebagaimana Allah dalam surat Al-Baqarah ayat 185

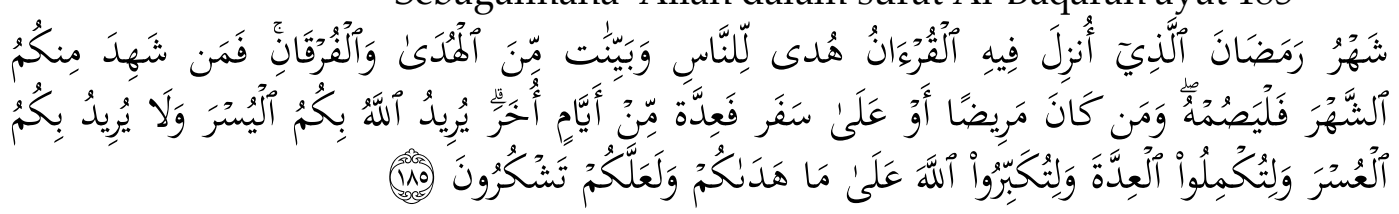

Artinya: ... Allah menghendaki kemudahan bagimu, dan tidak menghendaki kesukaran bagimu. dan hendaklah kamu mencukupkan bilangannya dan hendaklah kamu mengagungkan Allah atas petunjuk-Nya yang diberikan kepadamu, supaya kamu bersyukur. (Q.S.2:185).

Memberikan penjelasan merupakan salah satu aspek yang penting dalam proses pembelajaran. Alasan mengapa keterampilan menjelaskan perlu dikuasai antara lain : (a), Pada umumnya interaksi komunikasi lisan di dalam kelas didominasi oleh guru, sehingga materi sulit dipahami. (b) kemampuan peserta didik terbatas. Unsur-unsur keterampilan dasar mengajar dalam menyampaikan materi adalah rencana pesan yang akan, memberikan contoh teladan, Firman Allah dalam Al-Quran surat Al-Ahzab ayat 21 : 企 Arnya : Sesungguhnya telah ada pada (diri) Rasulullah itu suri teladan yang baik bagimu (yaitu) bagi orang yang mengharap (rahmat) Allah dan (kedatangan) hari kiamat dan Dia banyak menyebut Allah. (Q.S.33:21)

Menurut Wardani (1984:23) mengemukakan bahwa prinsip-prinsip penjelasan perlu dipahami antara lain : (1) penjelasan dapat diberikan di awal, tenggah, atau diakhir, (2) relevan dengan tujuan, (3) pertanyaan harus 
FITR AH Jurnal Kajian Ilmu-ilmu Keislaman

Vol. 03 No. 1 Juli 2017

dirancang dengan baik, (4) materinya berkualitas (5) menjelaskan materi relevan dengan tujuan.

Merealisasikan keterampilan dasar mengajar dengan mengunakan komunikasi berbasis pendekatan nilai-nilai Al-Quran. Nasehat disini dengan interaksi komunikasi yang lemah lembut sebagaimana Firman Allah dalam surat Ali Imran ayat 159. Artinya "Maka disebabkan rahmat dari Allah-lah kamu berlaku lemah lembut terhadap mereka. Sekiranya kamu bersikap keras lagi berhati kasar, tentulah mereka menjauhkan diri dari sekelilingmu. Karena itu maafkanlah mereka, mohonkalah ampun bagi mereka, dan bermusyawarahlah dengan mereka dalam urusan itu. Kemudian apabila kamu telah membulatkan tekat, maka bertawakallah kepada Allah. Sesungguhnya Allah menyukai orang-orang yang bertawakal kepada-Nya" (Q.S Ali Imran :.159).

Pemahaman ayat ini, peringatan kepada para dosen dan mahasiswa supaya berinteraksi dan komunikasi secara lemah lembut, bersikap pemaaf, bermusyawarah dan bertawakal. Pada surat Thoha ayat 44 Allah juga memberi peringatan supaya berkata lemah lembut dalam menyampaikan pesan-pesan pendidikan, walaupun dia orang yang ditakuti. Allah memberikan petunjuk bahwa bijaksama dalam berkomunikasi sebagaimanan Firman Allah dalam surat An-Nahl ayat 125 sebagai berikut Artinya : Serulah manusia kepada jalan Tuhanmu, dengan hikmah dan pelajaran yang baik dan bantahlah mereka dengan cara yang baik. (Q.S An-Nahl yata 125).

Ayat di atas memberi petunjuk bahwa kepada juru berdakwah dan pendidik bijaksana dan memberikan nasehat dengan baik. Ketiga ayat di atas menunjukan bahwa selama proses pembelajaran berlangsung diisyaratkan mengunakan komunikasi bil hikmah. Proses dan tujuan yang tersirat pada tiga ayat di atas tidak hannya fokus kepada ketrampilan dasar mengajar atau pengetahuan tertentu akan tetapi juga mencakup ranah afektif dan psikomotor dan kepribadian yang diujudkan dalam bentuk keyakinan.

Berdasarkan penafsiran ayat di atas, maka yang menjadi prinsipprinsip dasar dalam beretika dan berkomunikasi dalam proses pembelajaran adalah sebagai berikut:

a. Qaulan Karima ( perkataan mulia, QS.Al-Isra' 17:23 )

b. Qaulan Sadida ( berkata jujur, QS.An-Nis' 4:9)

c. Qaulan Ma'rufa (perkataan yang baik QS. Al.Baqarah 2:263) 
d. Qaulan Baligha (komunikasi yang efektif QS.An-Nisa' 4:63)

e. Qaulan Layyina (komunikasi yang lemah lembut QS, Thoha 20:44)

f. Qaulan Maisura (komunikasi mudah dipahami dalam bentuk lisan, isyarat atau tulisan, QS. Al-Isra'17:28).

Tampilan seorang guru dan dosen dalam pembelajaran di kelas akan digugu, dan ditiru, dan diteladani oleh peserta didik, tidak hannya menyuruh orang lain berbuat sesuatu akan tetapi dimulai dari diri sendiri sebagai mana firman Allah dalam surat Al-Baqarah ayat 44, artinya "mengapa kamu suruh orang lain mengerjakan kebaikan, sedangkan kamu lupa terhadap dirimu sendiri, pada hal kamu membaca Al Kitab, apakah kamu tidak berfikir.

\section{Menutup Pelajaran (close)}

Keterampilan menutup pelajaran merupakan keterampilan merangkum inti pelajaran pada akhir pengal kegiatan. Kegiatan ini cukup berarti bagi siswa, namum banyak guru tidak sempat melakukan atau mungkin segaja tidak dilakukan. Menutup pelajaran (closure) yaitu kegiatan yang dilakukan oleh calon guru dalam mengakhiri kegiatan pembelajaran dengan mengemukakan kembali pokok-pokok pelajaran. Menurut hasil penelitian yang dilakukan oleh para pakar pendidikan menyatakan bahwa, kemajuan hasil belajar paling besar terjadi pada akhir pelajaran dengan cara memberikan suatu ringkasan pokok-pokok materi yang sudak dibicarakan. Kegiatan menutup pelajaran dilakukan bukan diakhir jam pelajaran, akan tetapi pada setiap akhir pokok pembahasan selama satu jam pelajaran. Inti kegiatan menutup pelajaran adalah :

1. Merangkum atau menarik kesimpulan inti pokok materi yang telah diajarkan.

2. Mengkonsolidasikan perhatian peserta didik pada masalah pokok pembahasan agar informasi yang diterimanya dapat membangkitkan minat dan kemampuannya terhadap pelajaran selanjutnya.

3. Mengorganisasikan semua pelajaran yang telah dipelajari sehingga memerlukan kebutuhan yang berarti dalam memehami materi pelajaran.

4. Memberikan tindak lanjut berupa tugas-tugas yang harus dikerjakan di rumah baik secara individu atau kelompok sesuai dengan materi yang 
FITR AH Jurnal Kajian Ilmu-ilmu Keislaman

Vol. 03 No. 1 Juli 2017

telah disampaikan, serta memberikan saran-saran serta ajakan agar peserta didik termotivasi dalam proses pembelajaran berikutnya.

Contoh: Ketika masuk mengucapkan salam dan membaca do'a secara rutin, mengisi daftar hadir, menyuruh peserta didik menyiapkan alat-alat tulis, calon guru langsung menyampaikan pokok bahasan. Setelah pelajaran selesai, nah anak-anak waktu sudah habis pelajaran kita dilanjutkan minggu depan, asalamualaikum warahmatullahi wabarakatuh. Agar kegiatan keterampilan dasar mengajar menutup pelajaran dapat dilakukan oleh calon guru secara efektif, maka diperlukan wawasan pendidik tentang menarik minat peserta didik mengikuti proses pembelajaran, membangkitkan rasa ingin tahu, dan memberikan motivasi yang tinggi.

Menutup pelajaran memberi makna kepada peserta didik, yaitu dengan menggunakan cara-cara yang relevan dengan tujuan dan bahan yang akan disampaikan. Hubungan antara pendahuluan dengan inti pengajaran serta dengan tugas-tugas yang dikerjakan sebagai tindak lanjut nampak jelas dan logis. Menggunakan apersepsi yaitu mengenalkan pokok pelajaran dengan menghubungkannya terhadap pengetahuan yang sudah diketahui oleh peserta didik.

\section{PENUTUP}

Melakukan praktek mengajar atau micro teaching merupakan suatu hal yang harus dilakoni oleh seorang mahasiswa dalam rangka mempersiapkan diri menjadi seorang guru. Dalam melakukan hal tersebut seorang guru harus mampu mengintegrasikannya dengan Islam. Hal ini perlu dilakukan dalam rangka menuju pendidikan yang lebih baik dan islami dalam rangka menciptakan peserta didik yang islami. 


\section{DAFTAR PUSTAKA}

Al-Quranul Karim

A.Chaedar. 2007. Contextual Teaching and Learning. Jakarta : PT. Mizan Media Utama.

Arend, Richard. 1997. Clasroom Instructional Management. Newyork : The McGraaw-Hill Company.

Beck, Joan. 2000. Meningkatkan Kecerdasan Anak. Jakarta : Rajawali Pers

Borg, W.R, and Gall, M.D. 1989. Eductional Reseacrh: An Introduction. London : Longman, Inc.

Bruce Joyce. 1980. Models Of Teaching-Second Edition. America : United State of America.

Departemen Agama RI, 2010, Al-Quran dan Terjemahnya, Jakarta: Direktorat Jendral Departemen Agama RI.

Departemen Agama RI. Al-Qur'an Dan Terjemahan. Jakarta : Departemen Agama RI

Dwight Allen and Kevin Ryan, Microteaching. University of Massachusetts and University of Chicago, 1969 by Addson Wesley Publishing Company,Inc

Eric Jensen. 2010. Guru Super dan Super Teaching. Jakarta : PT.Indeks

George Brown, 1991, Alih Bahasa L. Kaluge, Pengajaran Micro Program Keterampilan Mengajar, Jakarta: Air Langga Press.

Gordon, Ann Milles and Bowne. 1985. Begining and Beyond: Foundations in Early Childoon in Education. New York : Delmar Publishing Inc.

Hildegrand, Verna. 1986. Introduction To Early Childhood Education. New York: McMillan Publishing Company

James H. Mc, Millan, and Sally Schumacher, 1997, Reseach in Education, New York San Fransisco,

2011. Tips Menjadi Guru Inspiratif, Kreatif, Dan Inovatif. Jogjakarta : Di Undang-undang no.20 tahun 2003 tentang Sistem Pendidikan Nasional

Wina Sanjaya. 2008. Kurikulum dan Pembelajaran. Jakarta:Kecana Media Group.

Zainal Asril, 2012, Microteahing, Jakarta : PT. Raja Grafindo Persada.

2009, Panduan Kuliah Microteaching, Penggunaan Laboratorium, dan Praktek Pengalaman Lapangan, Jakarta: Al Bayan 
FITR AH Jurnal Kajian Ilmu-ilmu Keislaman

Vol. 03 No. 1 Juli 2017

MAQĀȘID ASY-SYARI'AH

PENGERTIAN DAN PENERAPAN DALAM EKONOMI ISLAM

AMINAH 